\title{
Ájax, Atena e os (des)caminhos da métis
}

\author{
FRANCISCO MURARI PIRES \\ Departamento de História \\ Faculdade de Filosofia, Letras e Ciências Humanas \\ Universidade de São Paulo
}

RESUMO: No Ájax de Sófocles, deve-se entender a intervenção de Atena, em que a deusa mobiliza a exposição do herói ensandecido diante de Odisseu, como uma representação, no âmbito de realização divina, do código heróico arcaico que preceitua vilipendiar o inimigo vencido como ato final de triunfo regozijante? A partir da crítica da fundamentação exegética desse entendimento, propõe-se uma interpretação que busca apreciar a trama trágica sofocliana relevando antes a obra do poder divino de Atena, cujo favor novamente direciona os feitos heróicos de Odisseu.

PALAVRAS-CHAVE: Ájax, Atena, Odisseu, Sófocles, métis, tragédia.

\section{I - A Raiva de Atena}

No Ájax de Sófocles, logo no-início, ainda no Prólogo, uma cena têm intrigado, senão perturbado mesmo, o zelo da crítica moderna em seu afã de melhor entender sua trama trágica. Ela situa a intervenção direta de Atena nos episódios. A deusa, pela revelação de sua palavra especialmente propiciada a Odisseu, já desfizera o enigma do misterioso massacre dos rebanhos ocorrido naquela noite, bem e plenamente declarando ter sido Ájax quem o perpetrara. E, finalizando esse seu pronunciamento, dispôs-se ainda Atena a expor o próprio criminoso defronte à presença de Odisseu (presença esta de que Ájax, entretanto, não teria ciência), para que o herói assim se certificasse da realidade do fato que seu saber divino acabara de lhe revelar.

A deusa então chama Ájax para fora da tenda, e põe-se a inquirir o herói sobre a obra de seu recente feito noturno, que a tivera por "aliada". Assim, dolosamente, enseja sucessivas e exacerbadas manifestações de vanglória a um pretenso vitorioso que, vingativo, tripudia sobre a ruína dos inimigos supostamente por ele derrotados. Como, todavia, tudo não passa de uma ilusão demente de Ájax, justamente ensandecido pela própria deusa, cuja intervenção o desviara da consecução mesma de seus intentos homicidas, o que se tem, de fato, é, pelo contrário, a ruína do próprio herói, ironicamente ludibriado pelo insidioso concurso daquela enganosa assistência divina.

O vilipêndio contra a honra do herói assim resultante de seu desvairado feito é de tal ordem, e tanto o apequena e humilha, que mesmo Odisseu, apesar de seu inimigo ferrenho, compadece-se com seu infortúnio, pois se cientifica da fragilidade da condição humana e da 
consequente transitoriedade de sua fortuna, que num instante reverte o mais grandioso dos homens no mais ínfimo.

Cena de impacto tão chocante para a (in)compreensão da crítica moderna que ela se vê imediatamente compelida a entender as razões que justifiquem, ou não, a ação da deusa. Seria justo e condizente aquele espezinhamento infligido contra o herói? Seria próprio e condigno da grandeza divina? Não teria havido exagero e desmedida da parte de Atena? Assim, logo aventaram-se razões mais propriamente subjetivas escavando-se as falhas do caráter da deusa, mais particularmente atribuindo-se aqueles desmandos de sua punição vingativa contra o herói às mazelas de sua natureza feminina, até mesmo patologicamente sádica, a comprazer-se em torturar o adversário. E, assim, compuseram-se críticas indignadas a desqualificar a revoltante concepção do divino conformada pelo mito sofocliano. ${ }^{1}$

Em reação a tais enfoques distorcidos de (des)entendimento do texto, pesquisaram-se tambem razões mais objetivas, que, ao invés de judiciar os atos da deusa aferindo-os por sensos éticos anacrônicos a projetarem valores de outras historicidades, alcançasse suas justificações apropriadamente históricas, pois fundamentadas pelos conteúdos dos sentimentos religiosos helênicos e de seus valores civilizatórios mais geraîs. Nesse sentido, a fundamental análise de B. Knox (Knox, 1979), valiosa por inúmeras contribuições interpretativas, veio a praticamente cristalizar um entendimento equacionador dessa questão, buscando identificar as ordens de razões que melhor compreendam, em sua historicidade própria, os desígnios de Atena ao obrar aquela intervenção por que ela leva Odisseu a defrontar-se com Ájax. A ação da deusa, assevera esse autor, conforma a mais plena realização daquele preceito ético de conduta heróica, arcaico mas ainda atual no século V, que proclama:fazer o bem aos amigos, o mal aos inimigos. Ájax, outrora, ofendera a honra de Atena, sendo, pois, seu inimigo. Ela, desde então irada, agora se vinga: arruína plenamente seu adversário, e assim vitoriosa, regozija-se em tripudiar sobre o derrotado. Vai rir de sua humilhação vergonhosa, escarnecer de seu infortúnio inglório, espezinhar seu destino desonroso. Então, convida seu protegido Odisseu, também inimigo de Ájax, a associarse a ela nesse gozo próprio do triunfo, entregando-se às mais sarcásticas zombarias a vilependiar o adversário vencido. ${ }^{2}$

A argumentar a fundamentação textual desse entendimento, a obra hermenêutica da crítica moderna articula a composição de dois pronunciamentos da trama trágica sofocliana. Um deles, mais adiante no desenrolar da peça, é a palavra profética de Calcas. Por ela se desvenda a origem da ira de Atena para com Ájax. O fato ocorrera em meio aos combates troianos. Atena viera associar-se ao herói em seu empenho beligerante, exortando-o e instando-o a contra os inimigos voltar mão cruel. Mas Ájax, recusando o auxílio da deusa, retrucou-lhe esta terrível e nefanda palavra(vv. 774-5):

soberana, perto dos outros argivos

fica; por nossa linha jamais romperá a luta.

Essa a razão original da raiva de Atena. $\mathrm{O}$ outro pronunciamento encontra-se imediatamente antes da referida cena, e é a sugestão com que Atena intenta induzir Odisseu a que este presencie sua entrevista com Ájax, então persuadindo a boa disposição do herói nesse sentido ao lhe interpelar interrogativamente:

\section{Então o riso mais doce não é rir dos inimigos? (v. 79)}

Assim, conjugando-se os alcances daquele pronunciamento de Calcas, revelador da ira de Atena, com o da sugestão desta proposta divina de que o riso mais doce é o rir do inimigo, bem se constrói a hermenêutica textual das razões que dão o sentido e a finalidade do tripúdio de Ájax por Atena, consumado por aquela cena inicial da exposição do mesmo perante Odisseu: certamente impiedoso, mas não menos justo, desafogo vingativo do ultraje recebido. Assim o teria concebido o desígnio tramado pela raiva da deusa. 
E entendimento hermenêutico este que, então, é similar ao determinado pela ótica mais subjetiva de compreensão do ocorrido, elaborada pelo herói mesmo, pois foi acusando-o como ato impiedoso da deusa colérica, de humilhante espezinhamento de sua honra, que Ájax lamentou seu desfecho, dele ressentido contra Atena, cujo ludibriante poder divino causara sua ruína (vv. $367 ; 401-2 ; 426-7 ; 450-6 ; 656)$.

Entretanto, algumas interrogações ainda intrigam nosso entendimento. Pois, quando Atena mesma declara o propósito por ela vislumbrado para aquela exposição de Ájax defronte a Odisseu, a finalidade então expressamente alegada pela deusa enquanto sua razão de ser é outra, que não propriamente esse espezinhamento tripudiador do inimigo derrotado. Assim, ela diz a Odisseu apenas o seguinte (vv. 66-7):

\section{Mostrarei tambem a ti, manifesta, essa doença, para que a vejas e proclames a todos os argivos.}

Então, a finalidade e o sentido da cena da exposição de Ájax perante Odisseu, nos termos em que ela foi conformada pelo mito sofocliano, seria tão carente de sentido que, para bem compreendê-la, é preciso que nós, crítica moderna, além e sobre a alegação mesma de Atena, ainda tenhamos que (retro)projetar o sentido do fato da ira de Atena, todavia narrado por Sófocles só bem mais adiante no evoluir da trama trágica? Pois, só assim, ao sabermos do furor de Atena contra Ájax, causado pela desonra por este consumada contra ela (o que faria da deusa uma inimiga do herói), podemos apropriadamente entender como a finalidade determinante daquela proposta, a sobrepor-se às expressas alegações externadas por Atena mesma a Odisseu, ser um convite para que este se associe a ela no riso espezinhador de triunfo com que ambos se regozijariam diante da derrota vergonhosa daquele seu inimigo comum? Então, o sentido da cena inicial só bem e plenamente se realiza graças a uma tal operação assim teleologicamente arquitetada? $\mathrm{Ou}$ essa hermenêutica teleológica é antes um fato da leitura do texto, e mais precisamente de seus malabarismos analíticos?

E, se as proclamações hibrísticas de Ájax, a soberbamente dispensarem o concurso do favor divino para o êxito de seus empreendimentos heróicos, comportam, não só a ofensa pessoalmente dirigida contra Atena, mas também uma similar genérica abrangendo os deuses todos, por que é apenas o poder divino da ira de Atena que o persegue? E, se tais manifestações hibrísticas atualizam-se na história heróica de Ájax desde o seu princípio, por que razão $o$ desencadeamento da ira de Atena, causa de sua ruína, só se efetiva por ocasião do episódio do Juízo das Armas, em (con)sequência dele, e não já antes, em qualquer outra ocasião anterior, apenas (con)sequente àquela transgressão injuriosa contra a honra da deusa? Poderia o mito da tragédia de Ájax ter também memorizado uma especial determinação do destino de sua história através de um significativo embricamento episódico em que é a ação do herói que mobiliza tragicamente a atualização da raiva dessa deusa, justamente porque tal ação introduz o herói no âmbito precípuo de honra do poder de Atena?

Então, retomemos a trama mítica desde o princípio.

\section{II - A Métis de Ájax}

O herói fora desonrado e traído.

Ájax, ele que, em Tróia, terrível braço guerreiro, fora sempre só ousadia, coragem e intrepidez de desempenho por devastadoras batalhas, a assim, êmulo heróico, reiterar os precedentes feitos gloriosos de seu pai, Télamon (vv. 364-5; 434-40). Ele, guerreiro como o qual Tróia não vira na tropa vinda da terra grega (vv. 423-5). E, todavia, os argivos, ao votarem a concessão das armas de Aquiles, dadas como prêmio ao melhor dos aqueus, o haviam preterido em favor de Odisseu, contemplando, na pessoa deste, a distintiva e superior excelência astuciosa reclamada 
para a devida finalização ruinosa da guerra troiana. ${ }^{3}$ Haviam dele, pois, arrebatado as armas cuja posse, por honra, a ele deveriam caber (vv. 98-100). Os dois reis, aqueles Atridas, entretanto, desdenharam seus triunfos, usurpando-as (vv. 441-6). E em favor de quem? De Odisseu, finória raposa, velhaco, o mais imundo biltre da tropa! (vv. 103; 379-82; 389)

Assim Ájax, desonrado e traído por seus próprios companheiros, a quem ele sempre antes fora leal e solidário, ruminava furores rancorosos contra todos os argivos, mormente contra os Atridas, centros personificadores de poder e decisão régios na comunidade dos aqueus expedicionários contra Tróia; e, em especial, contra Odisseu, o adversário que o vencera naquela disputa, personificação emblemática da métis. Desonra e traição insuportáveis.

Mas, ele se vingaria! Tramou o plano de um massacre, a exterminar tais agentes traiçoeiros de desonras e a, assim, anular suas disposições rapaces de armas (vv. 98-100; 449).

Todavia, vingança que requeria empreendimento guerreiro formidável, de ingente envergadura heróica: nada menos do que, por uma só ação agressora, eliminar os chefes argivos mais suas tropas, todos eles magníficos e portentosos heróis, extremados em valor guerreiro! Como assegurar o êxito de uma, entretanto, tão arriscada e temerária façanha?

Um cálculo equaciona a solução viabilizadora do sucesso do feito. Já outrora, imerso nos combates da guerra troiana, o herói claramente expressara esse entendimento. Travava-se então, terrível, a disputa em torno do cadáver de Pátroclo, e Zeus já assinalara a ocasional vitória troiana, velando o Ida de nuvens e troando forte por raio lançado a abalar o monte. Os aqueus partem em debandada. Ájax, ciente dos desígnios divinos, cuida, ainda assim, de salvar o corpo do companheiro. Mas a névoa turvadora recobre o campo e obsta o pleno desempenho de seu valor bélico. Então, o herói clama uma prece ao Cronida (Ilíada, XVII.645-7):

Zeus pai, mas tu livra de sob a neblina os filhos dos aqueus, e faça céu fulgente, e conceda-nos vermos com os olhos.

Depois, em plena luz, arruine, visto que assim te agrada.

A Zeus pai queixa-se amargamente Ájax: como pode um guerreiro, por mais valoroso e corajoso que seja, combater heroicamente em meio a trevas? Como, então, bem se defender de um inimigo que agride oculto, cuja presença e ação ofensiva não se deteta nem se localiza? $\mathrm{Na}$ situação dessa desvantagem, a morte é certa! Que seja esta a determinação do desígnio divino, Ájax bem acata. Mas, então, que pelo menos lhe conceda a morte gloriosa, viabilizando a atualização de seus valores heróicos, possibilitando-lhe defrontar agressores: assim, combater à luz do dia, condição de desempenho bélico valoroso de coragem e intrepidez. Esse, então, é o cálculo: agressor oculto, inviabilização de valor guerreiro de defesa, morte certa!

Daí, o apropriado doloso plano: atacará os chefes argivos oculto sob as trevas de alta noite, quando nem mesmo ardem mais as vespertinas flamas, assim atacando indefesos adversários, surpreendendo-os na impotência guerreira de seu sono (vv. 15; 285-6; 291). Então, apropriada vingança: por métis os pune, ludibriante, pelo primado da métis consagrada na vitória de Odisseu porque o desonram. E, ainda, justa vingança: por traição os arruina, implacável, em contrapartida à traição porque o desgraçam.

E executaria o feito reiterando o modo e princípio mesmo de seu agir heróico: sozinho! (vv. $47 ; 294 ; 467 ; 614 ; 796)$ Absolutamente só, dispensando todo e qualquer ajuda e cooperação de companheiros. Tal era seu princípio heróico.

Então, já alta noite, quando vespertinas flamas não mais ardiam, sai de sua tenda empunhando bigúmeo gládio, e precipita-se, sozinho, em sua empresa, investindo dolo assassino contra os chefes aqueus, agora por ele odiados como seus traiçoeiros inimigos (vv. 285-91).

Alcança já as portas dos chefes Atridas. E, surpreendentemente, eis que ouve a voz de Atena a seu lado, a insuflar seu ânimo belicoso naquele empreendimento homicida. Inesperada assistência divina, pois nem então solicitada pelo herói! 
Logo se entrega ao furor da matança, assim excitado pela assistência da deusa a seu lado: brande contra aqueles dois a mão armada, e deixa-os mortos (vv. 49; 97-100); a seguir, afunda a espada na argiva tropa, e ainda liquida mais outros chefes; por fim, depois que descansou dessa cruentação, fez prisioneiros, levando-os atados para sua tenda (v. 95). Malévolo, cuida, em especial, de um cativo, Odisseu, a finória raposa, inimigo mais odiado, preparando-lhe sorte maior: prende-o à coluna do teto de sua barraca, reservando-o para o suplício de um vergastamento prolongado até a morte, desde já castigando-o com o látego duplo de grande rédea equina, a seus sons sibilantes fazendo acompanhar insultos de palavras vis (vv. 56-65; 101-10; 239-44).

$\mathrm{E}$, orgulhoso, exulta com seu feito. Ironiza, sarcástico, os inimigos vencidos, já zombando dos chefes Atridas e seus injustos pendores rapaces de armas, desafiando-os, agora cadáveres, a reiterarem aqueles seus modos de governar (vv. 97-100). Também contra Odisseu dirige palavras de zombaria (vv. 103-6). E, por tal humor vitorioso, regozija-se em sua vingança, rindo às gargalhadas da desgraça dos inimigos, ato último de vilipêndio com que sela sua desonra de derrotados (vv. 301-4).

Foi assim, por esses termos, que Ájax, já no dia seguinte ao massacre daquela noite, concebeu a memória daquele seu feito guerreiro, agora paradoxalmente contando com o favor do concurso divino de Atena, naquela ocasião sua inesperada aliada.

Só que tudo não passava de ilusão da mente extraviada do herói, então atacada de demência por obra de Atena.

\section{III - A Ciência de Atena}

Quando os aqueus despertaram daquela noite para mais outro dia de renovados combates no plaino de Tróia, depararam espetáculo catastrófico: todo o restante rebanho, butim acumulado de reiteradas incursões de saques e pilhagens por longos dez anos, fora destroçado; junto, também vítimas do massacre, os guardas mortos. Os modos do abate cruento indiciavam ação humana, não ataque exterminador de feras vorazes (Kamerbeek, 1963, p.24, nota ao v. 8). Misterioso acontecimento: no furtivo da noite, oculto por suas trevas, alguem exterminara rebanhos e guardas, deixando as evidências do crime perpetrado, porém eliminando suas únicas testemunhas oculares.

Então, uma suspeita, imediata e consensual entre os aqueus todos, a aventar o malfeitor: Ájax, a quem atribuem o ato criminoso (v. 28). Supostamente, intrigante sequela do Juízo das Armas, alguma desfeita estapafúrdia à sua desdita recente, preterido que fora pelos aqueus na contemplação da honra da herança heróica de Aquiles.

E suspeita logo alimentada por um testemunho: alguém afirmava ter avistado Ájax, sozinho, a saltar pelo prado, transitando, pois, suspeitamente pelo local do crime, espada recémaspersa (em sangue) (vv. 29-31). Mas, testemunho que, embora de valor inculpatório, ainda frágil, insuficiente enquanto prova, pois testemunho apenas indireto, compondo simples ato declarativo de suspeita, sem implicar necessariamente Ájax como o executante daquele preciso ato de massacre.

Então, a determinação heróica de Odisseu, movida pelo antagonismo que agora o opunha a este seu ferrenho inimigo, levou-o à iniciativa de realizar mais outro feito: encarregou-se do penoso trabalho da investigação daquele misterioso crime (vv. 1-2; 18-20;24). Tencionava apreender a verdade do ocorrido, dissipando a nebulosidade que turvava sua compreensão e esclarecimento. Almejava, alcançar um conhecimento certo do fato, transparente em sua visão do ocorrido, que superasse aquela insegura errança cognitiva das suspeitas ainda incertas, conformando verdades apenas hipotéticas (vv. 21-4). Porém, feito investigatório de apuração da verda- 
de singularmente dificultado, pois crime obscuro, de visão opaca, já que envolto por trevas de realização noturna e sem deixar testemunhos de olhos humanos que, justamente por tê-lo presenciado, pudessem relatar o ocorrido, bem o esclarecendo.

Assim, pôs-se à caça investigatória daquele seu inimigo.

Partiu dos vestígios deixados manifestos pelo ato perpetrado: impressões de pegadas no chão apontavam uma pista investigadora. Perícia nesta arte do rastreamento de um percurso de busca igualmente assinala uma excelência odisséica: compondo, como cadela lacônia (princípio híbrido de faro canino e manhas de raposa) (Kamerbeek, 1963, p. 20, nota ao v. 8), os recursos apropriados de discernimento perseguidor mais acuidade astuciosa, o herói pôs-se a seguí-las, perfazendo sua trilha. Assim reconstituiu o itinerário da ação perpetrada, e examinando os aspectos de sua efetividade impressora avaliou a atualidade de pegadas recentes. Então descobriu itinerário inconfundível, conclusivamente certo de um só possível agente, Ájax, pois caminho finalizado por um único e singular alcance mais longínquo, atingindo o ponto extremo do acampamento das náus, precisamente onde aquele herói posicionara sua tenda pessoal (vv. 3-7). Itinerário, então, que indicia a suspeita presença de Ájax na tenda e, portanto, enseja vincular as condições desse seu estado lá presente com as circunstâncias da ação última atualizada no princípio do percurso, de que elas seriam, pois, seus resultados consequentes (vv. 1-7). Mas, ainda e novamente, conhecimento impreciso, eivado de limitações, compondo tanto certezas quanto confusões, pois exame inconclusivo das pegadas, umas reconhecíveis, outras não, elidindo a plena e clara identificação de seu agente causador (vv. 31-3).

Odisseu, em furtiva espreita, já se dispõe então a espionar o interior da tenda. Justamente nesse momento Atena intervêm, detendo a ação investigatória do herói.

Intervenção que situa o limiar delimitador dos alcances precípuos do conhecimento desse fato: o humano operado pela investigação de Odisseu, e o divino revelado pela ciência de Atena.

Pelo conhecimento humano excelentemente obrado pela investigação odisséica, a identificação de Ájax como o criminoso é praticamente segura. Aquela iminente visão do interior da tenda deste herói lhe ensejaria certificar-se de suas suspeitas iniciais, bem as corroborando, pois lá dentro se encontrava recolhido o herói, associado a tantos efeitos assinaladores do ato criminoso: homem com suor a gotejar do rosto e (sangue) das mãos assassinas, e barraca que era só espetáculo de cruenta carnificina, executada contra rebanhos de bois e ovelhas, todos já jugulados ou despedaçados, menos um animal, infortunado carneiro, ainda preso à coluna da tenda, mas já supliciado por vergastamentos de açoites a aguardar ainda mais torturas até o suplício final (vv. $9-10 ; 63-5 ; 219-21 ; 235-44)$. Então, fim de uma obra investigatória de ato criminoso que indicia seu agente perpetrante, pois gotejamento de suores e aspersões de cruores animais assim circunstanciados a tantos corpos das vítimas fundam conjecturas retrospectivas de uma singular ação assassina de rebanhos.

A soma de todos os indícios incriminatórios aponta a culpabilidade de Ájax.. Tudo levava a crer que fora mesmo Ájax quem massacrara os rebanhos! O conhecimento humano desse fato, assim alcançado pela arte da investigação odisséica, percorre a via de apreensão de uma justa verdade factual.

Todavia, nesse êxito se detêm todo o alcance da obra humana de apreensão da verdade do fato ocorrido, demarcando, pois, o seu fim enquanto êxito apenas parcial, limitado. Duas ordens de razões assim a delimitam.

Primeiro, essa obra investigadora, que infere conclusivamente ter sido Ájax quem cometera o crime, não pode, mesmo e apesar de estar bem fundada em razões de evidências comprobatórias, prover o conhecimento de uma certeza absoluta: ela, de fato, compõe conjecturas, que embora altamente plausíveis, referem verdades, entretanto, apenas hipotéticas. Não pode proclamar ter alcançado a luminosidade transparente da certeza absoluta dessa sua verdade. Pois, pelos huma- 
nos, este conhecimento de certeza plenamente verdadeira, enquanto percepção de clarividência transparente do fato mesmo, viabiliza-se apenas quando e porque derivada através da realidade cognitiva de seu presenciamento (isto é: saber o ocorrido por ter presenciado sua manifestação fenomênica, por ter estado presente à sua ocorrência). Clarividência cognitiva, então, neste caso inviabilizada dada a morte dos guardas, suas únicas testemunhas humanas oculares.

Mas, não é essa limitação a mais significativa e relevante, já que, quanto a apreender quem fosse o criminoso - Ájax -, tal obra humana de investigação indiciadora positiva conforma, de fato, uma via sucedânea de conhecimento da verdade desse aspecto de realidade do fato ocorrido. Só que, uma vez alcançada essa verdade - Ájax é o criminoso autor do massacre dos rebanhos -, o que mais, a partir dela, se poderia saber por essa rede de inferências indiciadas? Assim, que razões e motivos o criminoso tinha, pode-se ainda suspeitar circunstancialmente: é quase certo que se trate de alguma desfeita, ou mesmo vingança furiosa, daquele herói, em revolta indignada contra o resultado do Julgamento das Armas de Aquiles. Suspeita que, aliás, todos os gregos desde logo aventaram. Ora, mas por que, assim furioso, ele voltara sua sanha precisamente contra os rebanhos? Poderia haver algum sentido nesse ato a transcender o mero transtorno de comportamento causado por uma mente insana? Ou, antes, pelo contrário, apenas agira pelo despropósito e falta de razão mesma que define a loucura, esse extravazamento de atos quaisquer da demência extraviada? Aqui, a possibilidade da obra humana de conhecimento pleno da verdade desse fato detêm todo seu alcance, pois, a partir daqui suas conjecturas extraviam-se, perdem-se nas trevas mesmas projetadas pela loucura que já perdera e desencaminhara o próprio Ájax ao perpetrar seu ato criminoso sob a ação do ludíbrio de Atena!

Mas, no limite onde termina o alcance da obra cognitiva humana, avança a revelação da palavra divina da ciência de Atena, que justamente, pelo contrário, o plenifica. Assim, imediatamente antes de Odisseu consumar aquela sua visão espreitadora do criminoso recolhido no interior de sua tenda, exatamente então, intervém a emissão da palavra de Atena que encerra a ação cognitiva do herói em sua observação perscrutante. De imediato o favor do concurso da revelação dessa palavra divina antecipa a realidade fenomênica que aquela visão espreitante do herói tambem alcançaria se fosse efetivada: Atena declara a Odisseu que, lá dentro da tenda, encontra-se mesmo o homem por ele procurado, faces gotejantes de suor e mãos apunhaladoras (vv. 9-11). E, a seguir, Atena proclama o princípio de uma palavra divina que, então, encerra o érgon do exame cognitivo empreendido pelo sujeito humano (vv. 11-3):

\section{E tu espiares para dentro desta porta}

já não é mister, mas sim relatares por que tal afã tens, para que de mim, que sei, aprendas.

Assim, a ação sucedânea da ciência da deusa finaliza, portanto, o conhecimento apreendido pela ação cognitiva do herói. É pelo concurso da ação da ciência divina de Atena, então principiado a favorecer o encargo heróico de Odisseu, que se superam tais limites da cognição humana.

As revelações assim propiciadas pela deusa agora cientificam o herói, Odisseu, de todo o ocorrido. O que ele, corroborando-a por indícios assinaladores, conjecturava como suspeita, mas sem ter certeza absoluta, agora é asseverado como fato mesmo: sim, são de Ájax aqueles atos assassinos (v. 39). A causa que o mobilizara a perpetrar feito assim insensato também se confirma: propósitos de furor rancoroso consequente ao Juizo das Armas (v. 41). Então, e agora compondo já revelações insuspeitadas pelos argivos todos, e que mesmo a arte investigativa de Odisseu não indiciaria: ato que não comportava propriamente o extravazamento despropositado da demência furiosa, mas sim o projeto de uma causalidade precípua, que comportava a razão de uma finalidade maior, pois aquele crime não finalizava o massacre dos rebanhos mesmos, mas sim visava antes ao extermínio dos chefes aqueus. ${ }^{4}$ 
Assim, é pelas revelações da palavra de Atena, que o fato fica plenamente relatado por todas as tramas e modos de sua efetivação dolosa e de sua proposição criminosa, ainda esclarecidos, a seguir, os desvios de seu intento fracassado: fora ela, Atena, que transtornara a percepção do herói, fazendo-o confundir rebanhos por homens, desviando-o do justo alvo de seus propósitos assassinos (vv. 45-65).

Agora é Odisseu plenamente inteirado do fato, apreendido seu conhecimento cristalino graças às revelações da ciência de Atena, que aprofundam a percepção da razão vingativa daquele crime, revelando inclusive sua hostilidade traidora contra a própria comunidade aquéia. E só assim dissipam-se as trevas que a (in)compreensão da realidade da loucura de Ájax turvavam e perdiam a visão humana da verdade última daquele fato.

Então, como ato final de consecução da transmissão dessa verdade da ciência divina a plenificar o conhecimento humano alcançado pelo herói, Atena declara (vv. 66-7):

\section{Mostrarei também a ti, manifesta, essa doença, para que a vejas e proclames a todos os argivos.}

Atena dispõe-se, agora, a produzir uma manifestação fenomênica que viabilizaria, para Odisseu, uma sucedânea visão humana (com)provadora da verdade daquele fato revelado por sua palavra divina, a demência de Ájax, em sua plena consumação final. Logo declara o fim a que essa visão pretende: o herói, assim cientificado da verdade daquele fato, poderia, então, proclamála à comunidade aquéia. Com o que esta, já historiada publicamente a realidade informativa do acontecimento, poderia, por sua vez, então reunida em assembléia, melhor deliberar sua decisão a esse respeito (vv. 719-34; 749-83). Assim, encerrar-se-ia, plenificados seus fins, a missão desse novo e específico encargo heróico encetado por Odisseu: descobrir a verdade do massacre dos rebanhos.

E, a instruir Odisseu, Atena antecipa-lhe quais são os modos imperativos dele então reclamados para presenciar o defrontamento de Ájax. Primeiro, que o herói bem a ele se disponha, não se negue, antes mantenha sua presença por firme confiança. E melhor o tranquilizando, adverte-o a que não sinta ameaça à sua pessoa, receando desgraça por sua presença diante de Ájax. Pois, afirma a deusa, a realidade da percepção de sua presença por Ájax será por ela neutralizada, ao desviar do olhar deste a visão da figura odisséica. Assim, que o herói não tema e, pois, não recue. ${ }^{5}$

De imediato, então, a deusa põe-se a chamar a presença de Ájax para fora da tenda, diante das barracas, ali mesmo onde já se encontra Odisseu, para com este defrontá-lo. Todavia, então ocorre um impasse: eis que Odisseu se nega a participar do defrontamento!

\section{IV - A cautela de Odisseu}

Aqui alcançamos a cena crucial investida pela crítica para o seu entendimento das razões da ação da deusa ao propor esse defrontamento de Ájax perante Odisseu, e predominantemente, por essa crítica mesma, apreciada então como tendo por finalidade a impiedosa vingança da deusa a vilependiar seu inimigo derrotado que a desonrara, agora dele escarnecendo e ridicularizando em regozijo triunfante.

Mas essa cena é toda ela conformada por uma intriga, pois o que Atena propõe - defrontar Ájax perante Odisseu -, é justamente ao que Odisseu, entretanto, se indispõe: o herói obstinadamente se recusa ao defrontamento. E, ainda, são justamente os modos contrários aos dele reclamados por Atena que o herói atualiza como reação ao defrontamento: recua, receia, teme desgraça! 
Pelo contrário, à precipitação dessa via o herói, em ação consoante com a excelência de solerte prudência que o distingue superiormente, opõe contenções de acautelamento. Logo declara que de forma alguma irá se submeter a ele. E, assim, sua recusa obsta, inviabiliza a iniciativa da deusa (v. 74).

Para dissuadir o herói desta sua atitude renitente, Atena recorre então a uma estratégia argumentativa que percorre vários passos sucessivos de dissuasão. Primeiro, compõe uma provocação insinuadora de suspeitas vergonhosas, que aventam como instância determinante da recusa de Odisseu uma falha de seu caráter: vergonhosa covardia, indigna de um ser heróico (v. 75).

76).

Odisseu afiança-lhe que não se trata de covardia, mas ainda assim persevera a recusa (v.

Então, insiste Atena, se não há covardia subjetiva a ancorar de princípio tal recusa, mesmo assim há temor objetivo, consequente às circunstâncias do fato, pois denuncia alguém receoso do que possa acontecer. Mas, objetivamente considerado o defrontamento em suas circunstâncias contextuais, por que temer defrontar Ájax? Ele é, agora como antes, apenas um homem! (v.77)

Sim, retruca Odisseu, apenas um homem, antes e agora. Mas, de imediato, bem qualifica quem é esse homem: ainda seu inimigo (v. 78). Ambígua declaração! Por um lado, concorda com, e mais reforça, o argumento de Atena: por ser apenas um homem, não é Ájax para ser temido por Odisseu, tanto que não o temia nem antes, mesmo já então sendo seu inimigo. Isso não mudou: seu inimigo tanto antes quanto agora, não é por isso que agora o tema. Mas, por outro lado, declaração que também de Atena discorda: justamente porque ele é ainda seu inimigo, prolongase, como situação ainda não superada, uma potencial hostilidade a envolver aquele defrontamento. Assim, pode Odisseu aventar ainda algum temor por outra razão fundamentadora, algo que justamente tenha mudado, uma realidade nova, em vista do que ele ancora a perseverança de sua recusa.

Mas Atena, rápido, investe agora nova réplica persuasiva, intentando apanhar em falso a argumentação do herói pela brecha nela descortinada: se Ájax é o inimigo de Odisseu, eis mesmo a razão, não para evitar o confronto com ele, mas, pelo contrário, justamente ainda outra vez querer vê-lo, pois, já o tendo vencido, boa oportunidade de consumar até o fim sua vitória, completando-a pelo prazer de selar o vilipêndio desonroso contra o inimigo derrotado. Não é, então, o riso mais doce o rir dos inimigos? ${ }^{6}$

Mas Odisseu, de renitente cautela, não se deixa apanhar pela sedução desse prazer. Ainda temeroso do confronto, cujos receios até agora as declarações de Atena não dissiparam, o herói diz que se contenta antes por não gozá-lo, prefere apenas evitar o defrontamento. Insiste e persiste em que Ájax fique mesmo na barraca! (v. 80)

Diante da consistente e resoluta determinação da recusa de Odisseu, incontornável pelas vias sinuosas da persuasão discursiva da deusa que não dissiparam as nuvens de seu temor que o acautelava contra o defrontamento, Atena concede-lhe a admissão da razão que funda e justifica essa resistência do herói: é a demência de Ájax o objeto de seus receios, a recomendar-lhe evitar deparar-se com aquele inimigo em tal estado de insanidade (vv. 81-2). Pois, éssa é a mudança, a realidade nova: tem-se ainda um homem, ainda Ájax, ainda inimigo de Odisseu, mas agora louco. E qual loucura? Um Ájax tomado por essa singular mania furiosa de massacrar chefes argivos, a assim desafogar, vingativo, todo o ódio rancoroso que lhes votava, especialmente aos Atridas e a Odisseu, principais causadores de sua desonrosa privação das armas de Aquiles! Então, da parte de Odisseu, justa cautela de homem prudente, pois a que risco o induzia a via do defrontamento com Ájax, o insano inimigo, proposta por Atena? Deparar-se, frente a frente, com tal inimigo agora tomado por essa singular mania assassina! É isso que a proposta de Atena 
enseja-lhe acontecer: Odisseu, o chefe argivo mais odiado por Ájax, postar-se, assim, diante do louco homicida! E, agora, não se trata mais, como na noite anterior, da ilusão ludibriadora de tomar gado por homem, pois é Odisseu mesmo que ele terá ao alcance de suas mãos assassinas!

Não é, pois, a toa que Odisseu recuse a solução dessa via por que Atena intenta propiciarlhe a comprovação cognitiva da verdade que finaliza sua missão heróica. Assim, o herói, renitentemente desconfiado, situa ainda o impasse, a entravar a ação do concurso da deusa que o favorece. ${ }^{7}$

Atena, então, reconhecendo a justeza de tal temor, procura tranquilizar o herói, afiançando-lhe que não precisa assim temer, pois Ájax não o verá, mesmo estando perto (v. 83). Enigmática, incompreensível, e ainda, para o bem prudente Odisseu, suspeita garantia, pois, acautela-se o sempre desconfiado herói: sim, o homem está louco, mas não está cego! (v. 84) Como, então, Ájax não o verá?

Assim, pelo entrelaçamento da trama consequente do diálogo da ciência e do poder de Atena com a cautela prudente e solertemente desconfiada de Odisseu, conforma-se a solução que, superando as aporias do impasse circunstancial, plenamente viabiliza o favorecimento do concurso divino ao herói: Atena obscurecerá as pálpebras de Ájax, ainda que dotadas de visão! (v. 85)

De fato, proclama Odisseu, os deuses tudo podem, até mesmo realizar o (humanamente) impossível (v. 86). Tal, assim, uma visão que não vê e, pois, uma presença oculta! O que bem desfaz o impasse. Pois, a obtenção por Odisseu da prova clara, manifesta, da singular demência consumada pelo agir de Ájax, que então a proclamaria por todos os argivos, bem arquitetada pelo favorecimento divino de Atena ao herói, supõe, como sua condição efetivadora, o defrontar-se de Odisseu com Ájax, para que assim ele testemunhe essa manifestação; mas, supõe também, por implicação necessária de realidade da condição humana, a presença de Odisseu diante de Ájax, cuja detecção por este é, entretanto, a situação que Odisseu acima de tudo pretende evitar. Daí a solução divina: uma visão (por Ájax) que não vê (Odisseu) e, portanto, uma presença (de Odisseu) que presencia (Ájax), sem, todavia, ser ela mesma presenciada (por Ájax).

Agora, então, Odisseu acede à solicitação de Atena, prestando-se ao defrontamento com Ájax. Mas mesmo assim, quando não têm mais razões de temor para recusar o defrontamento, ainda então a prudência sempre alerta de Odisseu ainda lhe preceitua proclamar certa indisposição: declara que o faz e aceita, não porque seja do seu querer, seu desejo de fazê-lo; pelo contrário, se a decisão coubesse apenas ao seu querer, gostaria de me encontrar longe daqui, diz ele. O espetáculo que, pois, irá presenciar, não atende aos reclamos do seu melhor agrado, nem tampouco de sua mais precípua inclinação. Estes ânimos antes o indisporiam a defrontar-se com seu inimigo louco.

Assim é superado o impasse porque Odisseu obstava a realização do defrontamento. E, assim, a deusa instruiu a consecução da confiança do herói, por aquela mesma via de solução que ela, Atena, desde o início, já antecipadamente lhe declarara:

Confiante fica, e não como uma desgraça recebas

o homem: pois, desviado, eu impedirei que

o brilho de seus olhos veja tua figura. ${ }^{8}$

\section{V - A Métis de Atena}

Agora, livrada a via do defrontamento de Ájax perante Odisseu, o favor da deusa propicia a este a prova finalizadora daquela sua obra heróica de investigação do crime cometido por Ájax.

A deusa, identificando-se ardilosamente como sua aliada, de modo a evocar-lhe exultante gratidão pelo pretenso favor de sua assistência na consecução do empreendimento daquela 
noite, instiga o herói a relembrar todos os desígnios dos atos por ele então perpetrados. Ele, inflado de orgulho por seu feito supostamente exitoso, proclama regozijante como massacrara a argiva tropa, como tambem eliminara os dois Atridas, e como, ainda, aprisionara Odisseu, arrastando-o para a tenda a fim de lá supliciá-lo até à morte (vv. 89-113). E, assim, inciente da presença de Odisseu, tudo revela e, pois, tudo então confessa.

Pela obra, portanto, da métis de Atena, ao ludibriadoramente inquirir Ájax sobre os modos e as intenções de seu recente feito noturno, conforma-se em ato como que a acareação do criminoso, e é Ájax, assim enganado, levado a produzir plena e cabal confissão de culpa pelo crime cometido. E consecução de fim este justamente consoante com a efetividade própria de operação das manhas da arte astuciosa, pois, como, se não por ludíbrio, obter a revelação de um crime cujo segredo encontra-se totalmente encerrado no espírito do próprio criminoso, único agente humano a agora conhecê-lo? Revelação que, portanto, supõe o paradoxal concurso da cumplicidade de disposição de quem, entretanto, é justamente a ela contrário!

A obtenção humana da prova jurídica do crime, bem efetivada pelo concurso da ciência e da métis de Atena prodigalizadas em favor de Odisseu, agora finaliza plenamente aquela sua singular ação heróica de uma investigação criminal.

Então, a proposta, aparentemente sedutora, apresentada tão somente interrogativamente por Atena a Odisseu, constitui antes um dos recursos argumentativos da retórica persuasiva da deusa, com que ela trama viabilizar a realização desse defrontamento mesmo por que sua ciência divina finaliza a missão cognitiva do herói. Via de persuasão retórica, entretanto, obstada pela recusa renitente da parte de Odisseu, que cautelosamente a descarta. Recusa e descarte cautelosos que, depois, já consumada a exposição de Ájax diante de seus olhos, finalizam-se por justa consciência piedosa aprendida graças à obra de Atena que assim o levou a contemplar a miserabilidade da condição humana emblematicamente espelhada na figura de Ájax, herói outrora tão grandioso, agora não menos aviltado. E, assim, compaixão de Odisseu que a deusa mesma, então, devidamente reconhece como condizente ato piedoso do herói que apropriadamente têm ciência da fragilidade da condição humana, e a quem, portanto, os deuses justamente amam.

Outra vez a obra heróica de Odisseu mais sua consciência sapiente compõem o produto da orientação divina do favor de Atena, que prodigamente o instrui e ensina. Bem o reconhecera o herói desde o início, ao saudar a vinda da deusa (vv. 34-5):

Oportunamente chegas: pois sempre, tanto outrora como no futuro, sou dirigido por tua mão.

E, tambem, desde o princípio o proclamara Atena, ao interpelar o herói (v. 13):

para que de mim, que sei, aprendas.

Ao apelo sedutor aparente daquela proposta retoricamente interrogativa, Odisseu, graças à sua renitente desconfiança, resistiu, não se deixou apanhar, não enveredou por sua sedução. Ao, todavia, atribuirmos a Atena o desfrute desse mesmo riso sarcástico de vilipêndio como a finalidade a dar o sentido para aquele defrontamento dos dois heróis, pelo qual ela, então, "ter-seia exemplarmente vingado de seu inimigo" derrotado, não estaríamos nós, críticos modernos, a ingenuamente cair no engôdo persuasivo que, entretanto, Odisseu não caiu?

\section{VI - O Fim de Ájax}

Mas, então, afasta-se a presença de Atena, e desfaz-se a demência do herói. Ájax recobra a razão, e constata os efeitos de sua obra assassina: no interior da tenda depara apenas ruinas de mortos de ovina cruentação. Logo desespera-se, bate na cabeça e gane, arranca-se os cabelos. Depois, a perplexidade o paralisa, até que, retomando a capacidade da fala, indaga furioso a 
companheira que tudo assistira, ameaçando com terríveis palavras a que tudo lhe revele (vv. 30616).

Agora, ganha (cons)ciência dos atos perpetrados. A filha de Zeus, invencível deusa de torvo olhar, o enganara, depois de insuflar-lhe furiosa doença. Assim tomado por loucura, subjugado por extravio nefasto, olhar e mente desencaminhados, trilhou a via sinistra por onde apenas barafustou insanidades: errou a ensanguentar as mãos no gado argivo, não em seus chefes! Irrisória empresa de, entretanto, outrora primoroso herói: ele, o ousado, o corajoso, o intrépido em devastadoras batalhas, agora atualizava seu valor a atacar feras imbeles! (vv. 59; 123; 182-6; 206$7 ; 216 ; 337-8 ; 364-7$; 447; 452-3) Assim realizava pretensões de destino heróico de ironia ridicularizante, pois guerreava amigos, em vez de inimigos, e caçava, não feras selvages, mas animais domésticos, próprios de criação civilizada.

Obra negadora de um ser heróico. Quem clamava pela luz diurna como tempo próprio e condição de efetividade de sua presença heróica, e que combatia franca e lealmente a descoberto, agora realiza seu feito ardilosamente, ocultando sua presença sob trevas noturnas. Quem antes distinguia excelência heróica por superioridade de beligerância defensiva, figura de torre por sua pessoa e escudo protetor, agora intentava firmar primazia honorífica por ataques assassinos, atualizando areté dependente de espada maléfica e ruinosa. O herói, que antes primava pela previdência e discernimento de espírito, agora errava insane, mente desvairada. Planejara o êxito vitorioso, mas obtivera apenas desastre ruinoso. Quem bem intentara vangloriar-se insultante da desonra do inimigo vencido, era, pelo contrário, objeto, e não sujeito, de tal vilipêndio, pois o humor da vitória antes contra ele se voltava: já vê os Atridas a dele escarnecer, Odisseu a decerto gargalhar de prazer. Apreciara ter em Atena sua aliada, e todavia ela o maltratara até a perdição (vv. 363; 383; 454). Principiara por (re)afirmar, vingativo, sua honra, mas terminara desonrado. Buscara, como sempre, conquistar mais glórias, mas delas via-se despojado. Então, obra infamante, a deslustrar sua história (vv. 143; 217; 191;401-2; 426; 464-5).

O leal e solidário companheiro de combate, sempre dedicado a salvar seus amigos e, pois, a deles merecer gratidão, agora empreendia matá-los, era deles inimigo e vil traidor, objeto de seu ódio e revolta (vv. 618-20; 1266-7). Ele, o herói civilizador, baluarte na defesa e promoção da comunidade aquéia, sua potência de fundação e salvação, era agora, pelo contrário, seu agressor homicida, símile humano de forças caóticas de catástrofes naturais - fogos cósmicos, mais tormentas e tempestades de que irrompem raios e relâmpagos -, princípio só de desastres, destruição e ruína.

Assim, ao tempo do Juízo das Armas que consagrava entre os aqueus o primado heróico da métis, finalizou o feito doloso de Ájax, desempenho frustrado de uma iniciativa de vingança pelo âmbito desse especial modo de ação inteligente, esfera de honra do poder divino de Atena.

Conta-se que Ájax, bem no princípio de sua trajetória heróica, quando deixava sua casa para conquistar fama e glória nos campos troianos, desatinara ao negligenciar os conselhos paternos. $\mathrm{O}$ ancião, de prudente experiência, prodigalizando-lhe suas sábias instruções de despedida por conselhos de como piedosamente melhor deveria orientar seus atos, o advertira (vv. 762-5): Filho, com lança pretende triunfar - mas triunfar sempre com um deus.

Ele, entretanto, já cheio de empáfia orgulhosa, ignorara o conselho paterno, imponderadamente lhe respondendo:

\section{Pai, com os deuses mesmo quem não é nada conquistaria o triunfo; mas eu, mesmo sem eles, creio que hei de arrebatar essa glória.}

Assim firmava o princípio de conduta, a norma ética, por que comandaria seu ser guerreiro e, pois, seu destino heróico.

Depois, já em meio aos combates troianos, manifestara mais outra jactanciosa presunção, 
agora tão mais insensata quanto sacrílega, pois dirigira a uma deusa - a própria Atena, que bem viera associar-se a ele naquele empenho beligerante, exortando-o e instando-o a contra os inimigos voltar mão cruel - esta terrivel e nefanda palavra (vv. 770-5):

Soberana, perto dos outros argivos

fica; por nossa linha jamais romperá a luta.

Ájax, herói baluarte e torre, areté de capacidade guerreira defensiva, dispensa a ajuda de Atena: seu próprio valor guerreiro basta para suster a linha de defesa no ponto onde ele combate. $\mathrm{E}$, assim, ele pode, por proclamação ambivalente, tanto de despreendimento generoso para com os companheiros quanto de altivêz exacerbada para com a deusa, remeter a graça do favor divino para outros heróis.

Mas, já Homero dissera os modos desse princípio ético da heroicidade de Ájax, compondo-a por afinidade com o de Aquiles, o herói-extremo, e contraposição ao de Odisseu, o heróimeio. Assim, igual a Aquiles, confiante em sua coragem e na força de seus braços, puxara seus navios a acampar em um dos dois pontos terminais da linha aquéia, irrelevando preocupações de conclamar as defesas de mais apoios vizinhos, como antes o fizera Odisseu, o qual situara sua tenda bem no meio do acampamento, posição privilegiada para que o chamado dos companheiros fosse por todos bem ouvido. Ájax, como Aquiles, é herói extremo! (Ilíada, VIII.220-6)

Para Ájax, a melhor realização do valor heróico reclama a dispensa de todo concurso que eventualmente o minore, seja humano, a cooperação de companheiros, seja inclusive o divino, a assistência de um deus. Contar com tal concurso de um outro valor em seu empreendimento guerreiro significa admitir, em si mesmo, falta desse valor, cuja carência, então, aquele outro justamente preenche. Não, pelo contrário, Ájax confia irrestrita e incondicionalmente na total suficiência de seu próprio valor guerreiro, pleno e autônomo, a dispensar, portanto, todo e qualquer auxílio. Ájax é herói extremo porque entende não the faltar qualquer valor guerreiro a necessitar suprimento por outros.

E, assim, pois, sempre principiou todos seus atos heróicos, confiante na auto-sufuciência da potência de sua precípua areté guerreira, e sempre então exitoso.

$\mathrm{E}$, assim, também principiou aquele feito vingador de sua honra ultrajada, agora excepcionalmente enveredando pelas vias sinuosas das artes da métis, adentrando. pois, o âmbito de honra do poder divino de Atena.

Então, proclamações tão altivas de independência de princípio heróico quanto insensatas para quem quer que humano seja, mesmo que herói valoroso. Agora a história de Ájax, em seu resultado ruinoso consequente da própria atuação desse princípio heróico que ignora todo o concurso do favor divino, ensinava a lição da ciência de Atena para quem desonra seu poder, dele prescindindo a assistência na realização de obras no âmbito da métis. Pois, nessa história heróica, a graça do favor de Atena finaliza a prosperidade gloriosa de Odisseu, que a honra, enquanto arruina a de Ájax, que a dispensa.

Quem quer que humano seja, ainda que herói, deve conhecer o limite que estigmatiza sua condição. Diz Alcmeón de Crotona que os homens morrem pelo fato de não poderem juntar o princípio com o fim. Assim principiou, e assim, ao reverso do almejado por esse princípio, finalizou o ser heróico de Ájax, tragicamente enredando seu próprio destino.

\section{Notas}

1 - Para as indicações bibliográficas respeitantes à tradição moderna de interpretação do texto sofocliano, confiram-se os acirrados comentários críticos de Flávio Ribeiro de Oliveira (Oli- 
veira, 1994) em sua Dissertação de Mestrado, especialmente no capítulo I, em que desdobra as argumentações já desenvolvidas em um texto de B. Knox (Knox, 1979). Todas as citações em língua portuguesa da tragédia de Sófocles por nós feitas foram retiradas da primorosa tradução constitutiva desse Mestrado.

2 - O que, então, implica uma interpretação dissociadora dos posicionamentos dos personagens míticos conforme seu acolhimento, ou não, dos imperativos dessa ética: de um lado, Ájax e Atena, esta deusa por autonomia divina, aquele herói por grandiosidade distintiva, mais os Atridas, estes por mesquinharia egoista de meros detentores do poder; e, de outro, Odisseu, cuja recusa configura a modernidade de superação dessa ética arcaizante. O que, por sua vez, instaura uma conformação paradoxal de representações do mito, pois a deusa assim age, por um lado, em consonância com a práxis do herói que ela, entretanto, arruina e, por outro lado, em divergência com a práxi i iı herói que ela, entretanto, favorece. Daí o corolário hermenêutico então reclamado: os deuscis @icgos se permitem o que, pelo contrário, interditam ao humano, mesmo que heróico. Nem sempre, pois, devem, pelos humanos, serem tomados como modelos, pois preceituam a estes o reverso do que fazem! (confira-se, por exemplo, o artigo de Knox, 1979, pp. 129-31).

3 - Assim foi relatado nos poemas cíclicos, a Etiópida e a Pequena Ilíada.

4 - Ájax, 42-5. Já G. Méautis (Méautis, 1957, p. 24) chamou a atenção para este ponto. Também Knox (Knox, 1979, p. 129, nota 29, e p. 131) adverte para este fato; entretanto, ambiguamente (des)valoriza seu comentário, ao aqui enfatizar sua relevância por uma consideração cuja assertiva comporta valor antes tautológico, pois apenas declara a importância dramática do mesmo.

5 - Confiante fica, e não como uma desgraça recebas o homem: pois, desviado, eu impedirei que o brilho de seus olhos veja tua figura (Ájax, 68-70).

6 - Ájax, 79. A interrogação posta por Atena a Odisseu - Então, o riso mais doce não é rir do inimigo? - vale, assim, como expediente de argumentação persuasiva bem circunstanciada e determinada por um contexto específico de significação e alcance, atrelada mesmo à réplica do herói imediatamente antecedente. Ela não foi, portanto, formulada como se fosse uma declaração de princípio positivo asseverado pela deusa, no sentido de que ela, assim, partilharia, e ainda autorizaria, esse modo de conduta heróica. Pelo contrário, o princípio que, depois ao final da cena com Ájax, Atena expressamente consagra é bem o inverso, a negação desse princípio heróico (vv. 126-132). A argumentação de Atena, enquanto expediente de dissuasão retórica, vale, então, positivamente tanto quanto vale seu arrazoado anterior: afirmaria mesmo a deusa que Odisseu é covarde?

7 - Os comentaristas modernos, a aventarem as razões de Odisseu em sua recusa a defrontar-se com Ájax, parecem compor uma argumentação hermenêutica de operação teleológica, pela qual projetam para o momento próprio em que essa recusa é atualizada - o princípio da cena do defrontamento -, o sentido, entretanto, só plenamente efetivado por seu término e fím. Dão, pois, a elevada consciência odisséica da fragilidade da condição humana, e sua condizente piedade pela sorte adversa de Ájax - como a razão de ser firmadora de sua recusa em espezinhar daquele seu adversário, como fora então propugnado por Atena (confiram-se, por exemplo, as considerações de Knox (Knox, 1979, p. 130), e de Meier, (Meier, 1991, p. 231). Mas, quando Odisseu se recusa a participar do defrontamento com Ájax, antecedendo ao ato de exposição desse seu inimigo, ele não declara já que assim não o faz porque dele sinta piedade; pelo contrário, ele sente piedade de Ájax justamente depois da exposição, e precisamente porque presenciou o extravio da loucura e a miserabilidade do estado a que aquele herói, outrora tão grandioso, fora reduzido, a bem tirar daí a lição consequente a essa contemplação: a fragilidade da condição humana manifesta pela ruína de Ájax, mas que, por ser também genericamente a dele mesmo, suscita sua compaixão. Então, Odisseu se apiada de Ájax porque contemplou sua ruína, e não se negou a contemplar sua ruína porque se apiada dele. De modo que o 
preceito então por sua conduta assim consubstanciado, de não espezinhar e vilependiar triunfante a desonra do adversário vencido, constitui, não o princípio consoante à sua recusa, mas sim o resultado final de sapiência resultante da experiência a ele propiciada por Atena, fazendo conjugar ao princípio de prudência solerte do herói as instruções que sua ciência divina enseja. Para entedermos a recusa inicial de Odisseu bastam, pois, as razões por ele mesmo declaradas: os justos receios de expor-se aos extravios homicidas do inimigo ensandecido!

8 - Ájax, 68-70. Do verso 66 ao 89 conforma-se uma estrutura narrativa de composição em anel, de modo que os vesros 89-90 retomam precisamente o ponto da ação posto pelos versos 71-3.

\section{Referências Bibliográficas}

KAMERBEEK, J.C. The Plays of Sophocles. Part I, tradução inglesa de H. Schreuder, Leiden, E.J. Brill, 1963.

KNOX, B. Word and Action. Baltimore e Londres, John Hopkins, 1979.

MÉAUTIS, G. Sophocle. Paris, Albin Michel, 1957.

MEIER, Christian. De la Tragédie Grecque comme Art Politique. Tradução francesa de M. Carlier, Paris, Les Belles Lettres, 1991.

OLIVEIRA, Flávio R. de. Aias de Sófocles: tradução e estudo. São Paulo, USP, 1994.

SEGAL, Charles. Tragedy and Civilization. Cambridge, Harvard University Press, 1981.

PIRES, Francisco M. Ajax, Athene and the (de)tours of métis. Classica, São Paulo, 7/8: $195-209,1994 / 1995$.

ABSTRACT: In Sophocles' Ajax ought we to understand the action of Athena, by which the goddess moves Odysseus to contemplate the madness of Ajax, as a divine representation of that ancient heroic code which recommends to humiliate the vanquished enemy as a final act of triumph? Or, could we better undestand its tragic conception as a product of the power of Athena always directing Odysseus through his heroic missions?

KEY WORDS: Ajax, Athena, Odysseus, Sophocles, métis, tragedy. 